\title{
The Critical Juncture Concept's Evolving Capacity to Explain Policy Change
}

John Hogan

Technological University Dublin, john.hogan@tudublin.ie

Follow this and additional works at: https://arrow.tudublin.ie/buschmarart

Part of the Political Theory Commons

\section{Recommended Citation}

Hogan, J. (2019.) The critical juncture concept's evolving capacity to explain policy Change. European Policy Analysis, 5(2) pp. 170-189. doi:10.1002/epa2.1057

This Article is brought to you for free and open access by the School of Marketing at ARROW@TU Dublin. It has been accepted for inclusion in Articles by an authorized administrator of ARROW@TU Dublin. For more information, please contact arrow.admin@tudublin.ie, aisling.coyne@tudublin.ie,gerard.connolly@tudublin.ie.

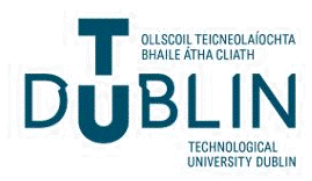




\title{
The Critical Juncture Concept's Evolving Capacity to Explain Policy Change
}

\author{
John Hogan
}

This article examines the evolution of our understanding of the critical junctures concept. The concept finds its origins in historical intuitionalism, being employed in the context of path dependence to account for sudden and jarring institutional or policy changes. We argue that the concept and the literature surrounding it-now incorporating ideas, discourse, and agency - have gradually become more comprehensive and nuanced as historical institutionalism was followed by ideational historical institutionalism and constructivist and discursive institutionalism. The prime position of contingency has been supplanted by the role of ideas and agency in explaining critical junctures and other instances of less than transformative change. Consequently, the concept is now capable of providing more comprehensive explanations for policy change.

KEY WORDS: Critical juncture, contingency, path dependence, ideas, policy

\section{以不断演变的关键时刻概念解释政策变化}

本文考察了对关键时刻概念的理解所发生的演变。此概念起源于历史制度主义，在路径依赖的 背景下得以应用，用于解释突发和不符合制度的变化或政策变化。笔者主张，围绕此概念的相 关概念和文献 (现包括观念，话语和政府机构) 逐渐变得日益全面和复杂，因为历史制度主义已 延伸到观念历史制度主义 (ideational historical institutionalism) 和建构话语制度主义 (constructivist and discursive institutionalism)。偶发性所占的重要位置已被观念和政府机构所扮演的角 色所取代，用于解释关键时刻和其他略低于重大变化的时刻。结果则是，关键时刻概念现能为 政策变化提供更多全面性的解释。

关键词: 关键时刻, 偶发性, 路径依赖, 观点, 政策

\section{La capacidad evolutiva del concepto de coyuntura crítica para explicar el cambio de política}

Este artículo examina la evolución de nuestra comprensión del concepto de coyunturas críticas. El concepto encuentra sus orígenes en el institucionalismo histórico, siendo empleado en el contexto de la dependencia de la trayectoria para explicar cambios institucionales o políticos repentinos y discordantes. Argumentamos que el concepto y la literatura que lo rodea, que ahora incorpora ideas, discurso y agencia, se ha ido haciendo cada vez más comprensivo y matizado a medida que el institucionalismo histórico fue seguido por el institucionalismo histórico ideacional y el institucionalismo constructivista y discursivo. La posición principal de la contingencia ha sido suplantada por el 
papel de las ideas y la agencia en la explicación de las coyunturas críticas y otras instancias de cambios menos transformadores. En consecuencia, el concepto ahora es capaz de proporcionar explicaciones más completas para el cambio de políticas.

PALABRAS CLAVES: coyuntura crítica, contingencia, dependencia de la trayectoria, ideas, política

\section{Introduction}

New institutionalism, and historical institutionalism in particular, has traditionally regarded the decisions made when an institution is formed, or policy initiated, as possessing a persistent influence. In the context of historical institutionalism, institutions are seen to encompass public policies (Capoccia, 2015; Peters, 2012). Explaining policy continuity has been historical institutionalism's strength. It has tended to focus on the macro processes of path dependency, "lock-in," and the inefficient histories that constrain possible futures (March \& Olsen, 1984; Pierson, 2000). Traditionally, with path dependence, the costs of reversing a policy path become increasingly high (Pierson, 2000). According to Rayner (2015), narrative accounts of path dependency are almost always subsumed under the larger rubric of the constraints imposed by the original path and the various positive feedback mechanisms that lock in actors. Policies, once initiated, would continue until a sufficiently strong force deflects them (Krasner, 1984, p. 240).

In these circumstances, institutional explanations for radical change have traditionally looked to exogenous factors. The results see history divided into long periods of stasis and brief instances of transformation. One of the concepts historical institutionalism has relied upon to explain such change is that of critical junctures (Mahoney, 2001). Critical juncture frameworks have evolved over time to differentiate between radical changes and other forms of transformation-driven both by exogenous and endogenous forces. This paper seeks to show how the concept was initially employed by historical institutionalists in thin ways that enabled them to avoid dealing with change during the juncture and has gradually developed over time into a thicker concept. This was not only because historical institutionalists acknowledged the need for a deeper conceptualization, but also because constructivist and discursive institutionalists brought ideas, discourse, and agency into the critical junctures concept. In this manner, the concept is providing new insights into policy change.

The first section examines the critical junctures concept's origins in historical institutionalism. We then look at the early frameworks developed to examine critical junctures, along with their insights, strengths, and limitations. Then, we examine the later conceptualizations of critical junctures, when interests, ideas, discourse, and agency acquired increasing significance. This leads to our example, showing what the earlier and later conceptualizations of critical junctures can tell us about policy change. 


\section{Critical Junctures and Historical Institutionalism}

The advent of new institutionalism, ushered in by March and Olsen (1984), points to the importance of temporality. Neo-institutionalism focuses on relationships between institutions and the actors active within them. Institutions constitute the formal/informal context that structures human behavior. New institutionalism quickly divided into three main schools, with the fourth, constructivist/discursive institutionalism, coming later. Of the three initial schoolsrational choice, sociological, and historical institutionalism-historical is of particular interest.

Thelen and Steinmo (1992, p. 2) define historical institutionalism as representing an attempt to illuminate how political struggles are mediated by their context. Early in its development, historical institutionalism included ideas, agents, institutions, and rules, but over time, it moved toward a more parsimonious approach (see Thelen \& Steinmo, 1992). "Historical institutionalism has followed March and Olsen's (1984) suggestion about de-emphasizing micro processes and focused on explaining complex processes and inefficient histories" (Rayner, 2015, p. 55). It argues that early choices have a persistent influence (Peters, 2012). The result has been that historical institutionalists focus on the process of path dependence, and lock-in, that narrows future options (Pierson, 2000). Questions of evolution and change initially attracted little attention (Thelen, 2004, p. 24). This has meant the reduction in agency for the sake of reducing outcomes to the logic of path dependency.

Path dependence seems to encourage scholars to think of institutional change as either minor and continuous or major and abrupt (Streeck \& Thelen, 2005). Thus, periods of institutional genesis are seen as corresponding to critical junctures (Abbott, 1997). This formative capacity of critical junctures is part of what made the concept intriguing. The junctures are critical as they place institutional arrangements on trajectories difficult to alter (Pierson, 2004, 135).

Critical junctures, caused by exogenous shocks, were relied upon to explain sudden punctuations to extant policy equilibrium (Baumgartner \& Jones, 1993; Krasner, 1984). The concept offered a framework for examining those rare moments of political openness in the evolution of an institution when new and enduring legacies can be formed (Capoccia, 2015). However, while path dependence brought the concept of critical junctures to wider attention, it impeded theorizing associated with it. Exogenous shocks removed the need to theorize about endogenous drivers of critical junctures and impeded recognition that the concept needed to be able to account for a spectrum of change.

"The assumption that institutional structures persist unless there are external shocks, underestimates both intra- and inter-institutional dynamics and sources of change" (March \& Olsen, 2005, p. 15). Most crises are followed either by policy continuity or by incremental change, not critical junctures. However, subtly and nuance in our understanding of the critical junctures concept were initially lacking. 


\section{The Early Critical Junctures Literature-Path Dependence}

From the emergence of historical institutionalism, critical junctures have been employed in providing explanations for change. This was particularly relevant in the context of path-dependent institutions, where continuity was understandable, but change was difficult to explain. The initial critical junctures frameworks were basic. As the concept was insufficiently specified, it was used as a catchall to explain change without sufficient justification. "Many of the key concepts needed to underpin analyses of temporal processes, such as path dependency, critical junctures, sequencing, events, duration, timing, and unintended consequences, have received only fragmented and limited discussion" (Pierson, 2004, pp. 5-6).

Not all events, even seemingly significant events, can reasonably be called critical junctures. A critical juncture must be an event, prior to which a range of possibilities exist, but after which these possibilities will have mostly vanished. It is at the narrowing point, where possibilities close that we seek a means of defining critical junctures. "Hence, not all choice points represent critical junctures; only those choice points that close off important future outcomes should be treated as critical junctures" (Mahoney, 2001, p. 112).

Mahoney's (2001) definition of path dependence sought to separate critical junctures of institutional formation from long periods of stability. Critical junctures establish pathways that funnel units in particular directions. Once units begin to move in a direction, they realize increasing returns and become locked in (Howlett, 2009; Mahoney, 2003; Pierson, 2000). This is akin to Baumgartner and Jones's (1993) concept of punctuated equilibrium. A critical juncture points to the importance of the past in explaining the present and highlights the need for a broad historical vantage point. Moreover, this necessarily "suggests the importance of focusing on the formative moments for institutions and organisations" (Pierson, 1993, p. 602). But, the problem has been the depth and understanding to which those formative moments have been examined.

One of the earliest uses of the critical junctures concept was by Lipset and Rokkan (1967, p. 48), where they located the beginning of the political party systems in Western Europe in three earlier critical junctures, the Reformation, then national and industrial revolutions. Early examples of the use of the critical junctures concept in historical institutionalism, embedded in antecedent conditions and path dependence, leave little room for discretion. This is because antecedent conditions "define the range of alternatives available to decision makers" (Mahoney, 2001, pp. 6-7). As such, agents do not have free choice per se; they do not begin with a blank slate. There was also the complication that the duration of a critical juncture could involve a relatively brief period in which one direction or another is taken or an extended period of reorientation (Mahoney, 2001). By extended period, we mean that the critical juncture could last for decades but with a shorter legacy.

The analyses also seemed to vary between the underlying societal cleavages, or crises, that precipitated critical junctures, or concentrated primarily on the critical junctures themselves, while overlooking the processes occurring during the 
critical juncture. Nevertheless, central to these approaches is an understanding that change is a cornerstone of comparative historical research and development, that historical institutionalism is incapable of explaining change (a violation of theoretical parsimony (Rayner, 2015), and that the critical junctures concept provides this opportunity.

Collier and Collier (1991) developed a framework for analyzing critical junctures in the trajectories of national development in Latin America. "The literature on critical junctures views them from the perspective of crises, placing particular emphasis on the tensions leading up to the critical juncture" (Collier \& Collier, 1991, p. 32). Antecedent conditions are identified as important-making the concept historical institutionalist in nature. Collier and Collier (1991, p. 29) define a critical juncture "as a period of significant change, which typically occurs in distinct ways in different countries and which is hypothesized to produce distinct legacies." Although their definition does not imply the primacy of agency over structure, its openness to longer term institutional innovation means that it does not provide a framework for determining at what point change is sufficient to constitute a critical juncture (Hogan, 2006). They regard the incorporation period in Peru, 23 years, as a critical juncture-when it looks like incremental change. This is at odds with Capoccia's (2015, p. 2) perspective, as he sees critical junctures as "shorter phases of fluidity and change alternating with longer periods of stability and adoption."

Mahoney's (2000, p. 535) conceptualization of critical junctures argued that the contingent period corresponded to the adoption of an initial institutional arrangement. He tries to explain why the liberal period in the 19th century, in five Central American countries, constituted critical junctures resulting in regime differences in the following century. For Mahoney (2001), while antecedent conditions were important, the decisions of those in charge were crucial, highlighting agency. However, as with Collier and Collier (1991), critical junctures are seen as having taken decades, while their aftereffects are often shorter. This raises questions about those periods of change, and whether they were in fact critical junctures. "To be able to recognize what is a critical juncture, we must be able to recognize what is not" (Hogan, 2006, p. 664). In response, Hogan (2006) introduced the notion that change in a critical juncture must be significant, swift, and enduring, wherein operational definitions would be dependent upon the researcher's understanding of the topic.

Garrett and Lange (1995, p. 628) argued that electoral landslides create critical junctures by producing overwhelming mandates for change. They looked at policy changes toward the trade union movement by the Conservative government under Thatcher in the United Kingdom (UK) in the early 1980s. Casper and Taylor (1996) argued that critical junctures can be used in analyzing periods when authoritarian regimes are vulnerable to liberalization. For them, a critical juncture (anything from a strike to a war) is a signal to potential challengers to indicate that the regime has weakened and an opportunity exists for a new political system. Examining the watershed in American trade policy that was the Reciprocal Trade Agreements Act of 1934, Haggard (1988, p. 91) argues that unanticipated 
events (critical junctures), in this case an economic depression, brings into question existing institutions and results in dramatic change.

Karl (1997) referred to multiple critical junctures in her analysis of how "petro-states" became locked into problematic development paths. She examined a range of countries for whom the discovery of oil led to instability. Gal and Bargal (2002) analyzed the emergence of occupational welfare in Israel using critical junctures. They argued that how the state was created, along with the collusion of competing interests in the labor movement, led to flat rate pension benefits. Vargas (2004) used critical junctures to examine the conflict in Chiapas, Mexico.

\section{The Limitations of the Early Critical Junctures Concept}

These understandings did not specify criteria with which to assess potential critical junctures to discover if they were critical junctures or changes of a different nature. Only early contingent events in the sequence matter as the subsequent events possess inertia (Howlett, 2009; Mahoney, 2000). Clearly, earlier events gave rise to path dependence and policies that persisted (Capoccia, 2015). The frameworks created to examine critical junctures tended toward understanding policy development as bipolar - either stable or undergoing periodic radical changes brought about by exogenous shocks (Boas, 2007; Howlett, 2009; Thelen, 2004). If critical junctures are of such importance, as their name suggests, then there was room for improvement. As we shall see, the improvements that came, varied and exciting, have resulted in the concept and its frameworks developing subtlety and sensitivity to various types of change through an appreciation of agency, interests, discourses, and ideas. That development is not only because historical institutionalists have acknowledged the need for deeper conceptualization, but also because constructivist and discursive institutionalists have come to employ critical junctures.

\section{The Deepening of the Critical Junctures Concept}

Since before the turn of the century, we have seen gradual evolution in the concept of critical junctures and a more encompassing understanding of institutions to include policies. These developments were initially driven by historical institutionalists with an interest in ideas and policies such as Weir (1992); Hall (1993) and Blyth (1997). I refer to them as historical institutionalists, as when they were writing and pioneering an explanatory role for ideas in new institutionalism, there was very little reference to ideational, constructivist, or discursive institutionalism (Hay, 2006). Cox (2001, p. 471) advocated using the constructivist perspective to expand the path dependence approach, as this specifies the pathshaping power of ideas, and individual action, to alter institutional configurations. Although she had previously alluded to it, Schmidt (2002) first used the term discursive institutionalism for the range of scholars using ideas and the interactions of discourse in an institutional context to explain change that may be either 
evolutionary or revolutionary. The implication is that incremental change and critical junctures can be in play simultaneously.

"Discursive institutionalism lends insight into the role of ideas and discourse in politics while providing a more dynamic approach to institutional change than the older three new institutionalisms" (Schmidt, 2008, p. 303). Discursive institutionalism's emergence marks the turn to ideas in political science (Ladi, 2011). In this context, institutions are contingent upon the involvement of actors (Peters, 2012, p. 124). From this perspective, to understand policy change, we have to understand the context in which agents think, speak, and act. Discourse contains not only ideas about policies but also the interactive process by which ideas are spread, and the context in which they are developed and promoted (Schmidt, 2008). For Schmidt (2008, p. 303), discourse "comes in two forms: the coordinative discourse among policy actors and the communicative discourse between political actors and the public." Coordinative discourse involves individuals and groups at the center of policy construction, those involved in the creation, elaboration, and justification of policy ideas, while communicative discourse involves individuals and groups active in the presentation, deliberation, and legitimation of political ideas to the public (Schmidt, 2008). In both types of discourse, the role of the agent is central and as a result, to be able to explain change, special attention needs to be paid to the agents and their interests (Ladi, 2011). Discourse links structure to agency.

"Discursive institutionslism is expected to shed light on the agency during those critical junctures through the study of ideas and discourse" (Ladi, 2011, p. 208). This approach will permit us to understand why all exogenous shocks do not cause the same kinds of contingent and enduring changes. However, for historical institutionalists, "critical moments are unexplainable times when structures shift, for discursive institutionalists these moments are the objects of explanation through ideas and discourse, which lend insight into how the historically transmitted, path-dependent structures are reconstructed" (Schmidt, 2008, p. 316). We will see that, during a crisis, various types of agents increase their actives, acting as carries of ideas and drivers of policy change as they engage in the coordinative and communicative discourse (Schmidt, 2008, 2010). In the context of critical junctures, agency ultimately concerns the choice of a specific policy option. The result is a critical junctures concept that has become capable of accounting for different types of change, identifying endogenous sources of change, and not just relying upon exogenous ones.

\section{The Later Critical Junctures Literature}

\section{Constructivist and Discursive Institutionalism}

Over time, historical and discursive institutionalist researchers have sought to develop better understandings of how critical junctures occur, what defines them, how to differentiate them from other forms of change, and how to theorize a critical juncture. While answering these questions may place restrictions on the liberty 
with which the term can be employed, we will be able to say with greater certainty what a critical juncture is.

The early frameworks generally lacked rigor-failing to offer a set of criteria with which to assess potential critical junctures. While acknowledging that developing a set of universally applicable standards would be impossible, moving in that direction would constitute an advance. These approaches seek to address the infinite regress problem, the agency problem, generative cleavage, contingency, and critical juncture duration. A clearer understanding of critical junctures would provide us with a break in the chain of causation with which to define the starting point for analysis.

Policies can be discredited due to their implication in, or inability to resolve, a crisis. When a policy is in difficulty, windows of opportunity appear, wherein change agents contest the viability of the prevailing paradigm (Kingdon, 1995). As early as 1992, Weir (188) sought to explore "when and how politics and ideas combine to produce policy innovation and why some ideas fail to influence policy." Hall (1993, p. 279) pointed out that ideas determine the path of subsequent policy, as policy-makers work within a framework of ideas and standards that specify not only the goals of policy but also the instruments to be used to achieve these goals. "Ideas facilitate the reduction of ... barriers by acting as coalitionbuilding resources among agents who attempt to resolve the crisis" (Blyth, 2002, p. 37). This is an ideational phase where "agents interested in reforming existing distributional arrangements contest the definition, meaning and solution to the problems identified by opposing ideologies" (Blyth, 1997, p. 234). That said, Hall (1993) has been criticized for an oversimplified critical juncture type change, seeing ideas as too static with a diminished role for actor agency (Matthijs, 2012; Wilder \& Howlett, 2014).

Golob (2003, p. 37) remarked on the increasing importance of ideas for critical junctures when she said "ideas are the casual mechanisms of change in any critical juncture." Thus, ideas found their way into the critical junctures concept within a decade of Hall's work on paradigms shifts. In 2005, Flockhart used critical junctures to explain the gap between Danish voters and their politician's attitudes toward the European Union (EU). She did this through the application of a social constructivist perspective on ideational change with theories of social learning and identity. For her, "ideational change usually happens as a rational reaction in response to external stimuli in the form of a destabilizing shock" (Flockhart, 2005, p. 262).

Hogan and Doyle (2007), following Flockhart's (2005) lead, employ interests, ideas, and agency to understand critical junctures, wherein variation results from choices and discourses. They argued that after an exogenous shock, ideational change, involving change agents and their interests, is crucial for radical policy change. They placed policy and political entrepreneurs, their interests and ideas, and their ability to assemble coalitions for policy change, at the heart of their framework, while drawing on Legro's (2000) work on ideational change. In this context, the presence of a crisis does not suggest a group of rivals is ready to implement a paradigmatic shift (Baumgartner, 2012, p. 15). But, once a new idea 
is adopted "policymaking becomes possible only in terms of these ideas" (Blyth, 2001, p. 4). The attention to entrepreneurial agency, and discourse, is an effort to "endogenize" policy change, diminishing exogenous shocks.

On examining the development of an EU counterterrorism policy through critical junctures, Wolff (2012) acknowledges that both exogenous and endogenous events and choices by actors can cause critical junctures and that not all shocks result in critical junctures. Interestingly, she suggests that a critical juncture does not always equate with change, since external events might constrain actors. This is akin to Capoccia's (2015) notion of the near-miss critical juncture. Drawing on Lindblom (1959), Wolff (2012) points out that most policy change is incremental.

Investigating the distinctiveness of critical junctures, Soifer (2012) focuses on "permissive conditions" - that create, in the words of Capoccia and Kelemen (2007), substantially heightened probability that agents' choices will affect the outcome of interest. These permissive conditions represent the easing of constraints making change possible. A critical juncture "is marked by the emergence and disappearance of permissive conditions" (Soifer, 2012, p. 1573). Permissive conditions bound the productive conditions that result in critical junctures. Productive conditions such as agency, ideational change, or contingency will shape the outcome of the critical juncture (Capoccia, 2015). Borrowing from Slater and Simmons (2010), Soifer (2012) points to the role of critical antecedents. These newer understandings of critical junctures do not rely on "purely contingent initial conditions to set trajectories in motion" (Howlett, 2009, p. 250).

According to Matthijs (2012), an economic crisis will result in a critical juncture when it opens the door to new ideas that can function as a blueprint for new institutions. This search for new ideas often leads to previously used ideas, which are adapted to address current problems by policy entrepreneurs acting as bricoleurs (Carstensen, 2011, 2015). In this way, ideas provide the basic conditions for successful collective action among actors interested in reforming distributional relationships (Blyth, 1997). To define a crisis, Matthijs (2012) draws on Legro (2000) and particularly on Blyth's (2002) ideational and discourse work looking for collapse of the extant orthodoxy. Matthijs (2012, p. 30) contends that "in the absence of a crisis, ideas will at most bring about incremental change."

Through applying critical junctures to the historical trajectories of institution building in East Asia, Yoshimatsu (2014) argues that contingent crises have had significant influence on institutions. During a crisis, actors undertake complex learning, leading to improved ideas that increase the legitimacy and acceptance of particular policies. "A critical juncture is regarded as creating the crucial conditions that encourage states to adopt a new policy for regional cooperation" (Yoshimatsu, 2014, p. 28).

\section{Historical Institutionalism}

These developments among scholars close to constructivist and discursive institutionalism have been followed by advances among scholars who remain more rationalist/historical institutionalist in approach. Similar to Hogan (2006), 
Capoccia and Kelemen (2007) argued that critical junctures should be "relatively short periods during which there is a substantially heightened probability that agents' choices will affect the outcome of interest." They wanted to move away from conflating critical junctures and gradual evolution. The duration of the critical juncture also had to be brief compared to the process it initiated. "In this analytical context, critical junctures are cast as moments in which uncertainty as to the future of an institutional arrangement allows for political agency and choice to play a decisive causal role" (Capoccia, 2015, p. 148). Capoccia (2015) also introduced ideas into his discussion of critical junctures.

To address infinite regress associated with causation in path dependence, Slater and Simmons (2010) developed a revised critical junctures framework to identify the main casual factors in political development. They focused on antecedent conditions that caused the critical juncture, while not denying contingency and agency (Capoccia, 2015). For Slater and Simmons (2010), critical antecedents are "factors or conditions preceding a critical juncture that combine in a causal sequence with factors operating during that juncture to produce a divergent outcome" (Slater \& Simmons, 2010, p. 889). Divergence is something Acemoglu and Robinson (2012) talked about in terms of minor institutional differences between England, France, and Spain at the start of the early modern period that led to different development paths. For Slater and Simmons (2010), the critical antecedent helps determine the differential causal effects of the independent variable across cases when the critical juncture occurs due to an exogenous event.

\section{Strengths of the Later Critical Junctures Concept}

This later research has seen greater theorizing as to what constitutes a critical juncture. As Howlett (2009) points out, there is an element of reactive sequencing in our advanced understanding of critical junctures. Each of these approaches possess greater rigor than in the past, being conditional on circumstances whether endogenous or exogenous (Schedler, 2007). These approaches offer a richer sense of how earlier outcomes shape later ones than was the case with contingent punctuations, or random starting points, and lock-in, associated with path dependency models (Howlett, 2009). Path dependence may have overstated the degree of stability in political institutions during more "stable times" (Boas, 2007, p. 34). While exogenous shocks still pay a role in critical junctures, a host of other factors are now used to explain the concept, particularly agency, ideas, and discourse. As Capoccia (2015) points out, these approaches yield fresh empirical findings and enhance conversations on policy change.

\section{Employing Old/New Frameworks for Identifying a Critical Juncture}

"Traditionally, students of institutional change focused on the importance of crisis" (Cortell \& Peterson, 1999, p. 184). Consequently, "an important part of the literature on critical junctures views them from the perspective of crises, placing particular emphasis on the tensions leading up to the critical juncture" (Collier \& 
Collier, 1991, p. 32). Wars, revolutions, coup d'état, economic crises, changing balance of power, electoral landslides, demographic changes, and social movements may produce an overwhelming mandate for policy and or/structural change (Cortell \& Peterson, 1999). This is because such unanticipated events can discredit existing institutions and policies due to their association with, or inability to right, the emergent situation, triggering change (Tilly, 1975). Figure 1 captures the early understanding of critical junctures.

However, the later critical juncture's literature recognizes that not all crises lead to radical policy changes and critical junctures. A crisis can call into question existing policies, bringing about the possibility of change (Haggard, 1988). Once a crisis is identified, the failure of a policy impels policy-makers to look for a solution-stretching the extant policy paradigm (Blyth \& Matthijs, 2017). This is possible as a policy paradigm must possess some malleability due to the regularly changing political context (Schmidt \& Thatcher, 2013). The failure of extant policies provides a window of opportunity for change agents to contest the viability of the underlying paradigm (Kingdon, 1995).

Hall (1993, p. 291) argued that exogenous shocks, and policy failures, discredit the old paradigm, leading to a reexamination of the belief systems through which that policy was created. According to Legro (2000), extant ideational collapse and new ideational consolidation are components of ideational change and the subsequent policy change process. Legro (2000) argues that if consensus is achieved, we will see change agents in the form of policy entrepreneurs coordinating a replacement set of ideas to the reigning consensus. The policy entrepreneurs will coalesce around a new set of ideas championed by a political entrepreneur (Carstensen \& Schmidt, 2016; Hogan \& Timoney, 2017). These new ideas, constituting a new paradigm, function as a resource for policy-makers (Carstensen \& Matthijs, 2018). Political entrepreneurs exploit the uncertainty created by crises (what Blyth (2002) terms as Knightian uncertainty), and "search for that mix of interests and appeals that can produce a winning coalition" to generate major change (Sheingate, 2003, p. 192). For new ideas to overthrow extant policies, the political entrepreneur must occupy a position enabling them challenge existing arrangements with the ideas generated by policy entrepreneurs. Political entrepreneurs act as a bridge between coalitions of various types of policy entrepreneurs advocating new policy ideas and the institutions implementing them (Hogan \& Feeney, 2012). They sit at the nexus of political power and policy ideas (Beland, Carstensen \& Seabrooke, 2016). However, "failure to reach consensus on a replacement could still produce

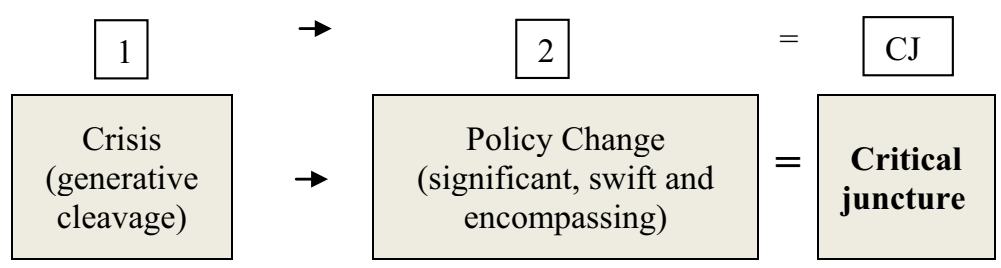

Figure 1. Early Critical Juncture Framework 


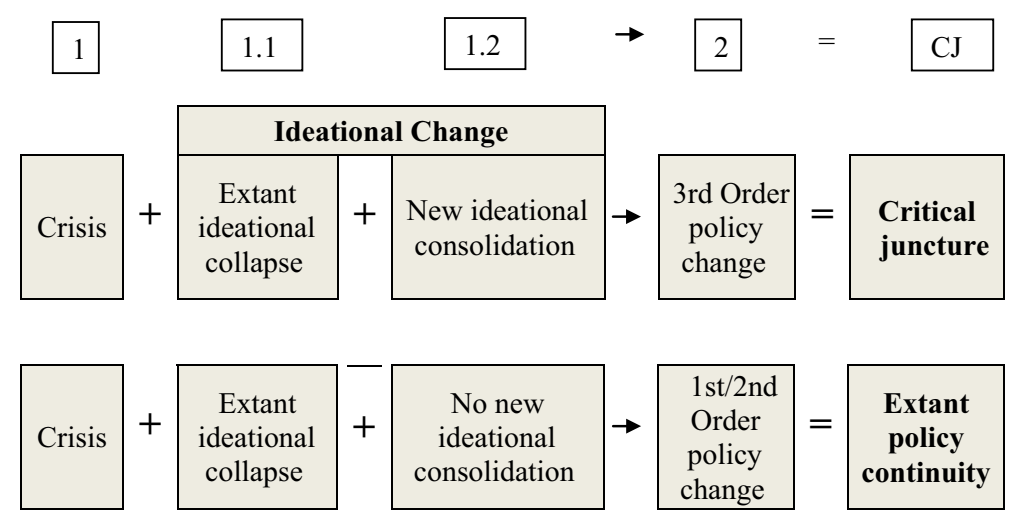

Figure 2. Later Critical Juncture Framework

continuity, as society reflexively re-embraces the old orthodoxy" (Legro, 2000, p. 424).

The nature of policy change is then examined in the context of the work of Hall (1993). This examination also takes account of Hogan's (2006) argument that change must be significant, swift, and enduring, and equally Capoccia's (2015) argument that it should be short and followed by a longer period of stability and adoption. This enables identification and differentiation of policy changes ranging from adjustments, to the settings of policy instruments, to the total transformation of policy goals as happened in the UK during the late 1970s, with the shift from a Keynesian to a monetarist approach to economic policymaking (Matthijs, 2012). This more nuanced understanding of critical junctures is set out in Figure 2. This is a significantly more complex framework than set out in Figure 1.

\section{Evaluation and Discussion}

Here, we will employ both of the above critical junctures frameworks. We will look at the Mexican government's changes to macroeconomic policy in 1982 to show how these frameworks' explain that change. When reading this section, the early framework is only concerned with sections 1 and 2, while the later framework is concerned with sections $1,1.1,1.2$, and 2 .

\section{Mexican Macroeconomic Policy}

Section 1: Identification of Macroeconomic Crisis. In the 1940s, Mexico adopted an import substitution policy. At the same time, the private sector became tariff dependent. Fiscal and monetary order collapsed under the Echeverria (1970-76) administration - a time of falling agricultural exports, rapid population growth, and middle-class disillusionment with single-party (Institutional Revolutionary Party [PRI]) domination (Edmonds-Poli \& Shirk, 2012). When Petróleos Mexicanos 
(PEMEX) discovered oil in the late 1970s, it only circumvented the dangers of immediate crisis without resolving the structural problems (Nelson, 1990, p. 95).

Mexico was a net oil exporter, and pressure grew for it to expand public spending. State ownership in enterprises quadrupled (Calderón-Madrid, 1997). Under President López Portillo (1976-1982), expenditure outstripped oil revenue and an anemic taxation system, overheating the economy (Solís, 1981). As a result, Mexico had to borrow U.S. $\$ 78$ billion (Alarcón \& McKinley, 1992). The peso rose in value as inflation rose, and the competiveness of exports, apart from oil, diminished (McCaughan, 1993).

Mexico was vulnerable when oil prices fell in the early 1980s. Compounding matters, PEMEX and the Budget Committee declared oil revenues insufficient to revive the economy (Ascher, 1999). Recession in the United States reduced demand for Mexican goods, while an increase in interest rates reduced the money supply and put pressure on Mexico's debt servicing. U.S. banks had lent Mexico $\$ 25$ billion, and the servicing of these debts surpassed its oil revenues (Pastor \& Castañeda, 1988). By 1982, as economic confidence waned, Mexicans began converting pesos to dollars (Looney, 1985). The gravity of the situation came to international attention on August 13, 1982, when

The government fired the shot heard around the world, announcing that it could not meet interest payments coming due within the next few days and initiating negotiations for bridge loans and rescheduling agreements with the U.S. Treasury, the IMF, and the private commercial banks. (Nelson, 1990, p. 97)

Mexico's economic indicators pointed toward crisis. Despite rapid economic growth during the late 1970s, GDP contracted by $4.2 \%$ in 1983 , and inflation reached $58.92 \%$. Output fell, real unemployment jumped toward 15\%, and more than 20 million people, half the workforce, were underemployed (Cornelius, 1985, p. 92). The budget deficit stood at $16.5 \%$ of GDP. Compounding matters, U.S. banks stopped lending to Mexican companies, as they already owed $\$ 600$ million in interest (Malkin, Greenwald \& Earle, 1983).

In 1982, the peso was devaluated twice to increase exports. New short-term loans were taken to counteract capital flight. Banco de Mexico's reserves dried up (Walker, 2013).

Section 1.1: Identification of collapse in ideas underlying macroeconomic policy. Traditionally, PRI presidents operated populist-redistributive models (Hellinger, 2013). In 1976, when López Portillo became president, he was forced to consider expenditure reductions due to the impact of the first oil crisis. But, with the discovery of oil reserves, he adopted a patronage model that incorporated expansive state expenditure with rapid industrialization (Bailey, 1980). Initially, this resulted in rapid growth, but as the economy grew reliant on oil revenues, it became increasingly vulnerable. 
Despite oil revenues, Mexico became increasingly dependent on foreign borrowing to meet its commitments. Once oil prices fell and interest rates rose, Mexico faced the prospect of default. In response, in early 1982, the López Portillo administration introduced a plan to stabilize the economy. The ideas underlying extant economic policy were coming under increasing strain. The international discursive shift to "neoliberal" politics in the late 1970s and early 1980s is a significant factor, especially relevant given the proximity of Reagan's United States. The Reagan administration had inaugurated policy-based lending whereby government agencies used debt relief as a lever to win market-orientated reforms from developing countries (Kahler, 1990).

The economic crisis dominated the 1982 presidential election. The PRI nominated fiscal conservative Miguel de la Madrid as its candidate, the result of shifts in a more conservative direction within the inner circles of the PRI (Sanderson, 1983). The choice marked a rupture from the party's revolutionary ideology. With the economy in crisis, and a sense that the PRI and traditional politics were failing to meet the challenges confronting the country, free-market advocates demanded a president who would support the rights of private property (Luna, Tirado \& Valdes, 1987). De la Madrid and his team's belief in economics and the market ensured that they were more receptive to the International Monetary Fund (IMF) and U.S. Treasury advice (Domínguez \& Castro, 2001). The ideas underpinning extant economic policy, focused on import substitution industrialization and protectionism, had clearly collapsed.

Section 1.2: Identification of consolidation of new ideas for managing macroeconomic policy. Throughout the campaign, which he ultimately won, de la Madrid emphasized the differences between his proposed government and the outgoing administration. In his inauguration address, he stressed that a new moral, political, and economic approach was needed (Smith, 1990). He acknowledged that Mexico was in an emergency. Locked into an IMF bailout negotiated by the outgoing administration, de la Madrid presented a program for change (Golob, 2003).

The range of options open to the government was limited. External financing had dried up in the aftermath of the economic crisis, and oil revenues remained stagnant. Even when oil prices began to recover, PEMEX was not able to take advantage. It was clear that, to maintain economic, political, and social order, a break with the past was required. Acting as a political entrepreneur, de la Madrid championed a new set of ideas on how to manage the economy. Change agents, led by de la Madrid, consolidated around this replacement set of ideas. These involved moving the economy away from import substitution and toward a more open approach to international trade and investment.

Section 2: Identification of macroeconomic policy change. New president De la Madrid appointed cabinet ministers from the conservative wing of the PRI who supported his efforts to stabilize and open the economy, prioritizing the attraction of FDI and focusing on high-tech industries (Philip, 2014). His first budget, 
aiming at reducing the deficit by $50 \%$, was draconian, and the budgets he sent to Congress in 1983 and 1984 represented a sustained austerity drive (Cornelius, 1985). The peso was pegged at a more "realistic" exchange rate, and plans were introduced to restructure the bureaucracy. De la Madrid introduced conventional monetary and fiscal austerity and more-extensive trade liberalization. The Mexican government also adopted a less confrontational approach to the IMF and was able to reach agreement on an adjustment program to revive the economy, which allowed it avoid a debt moratorium (Looney, 1985).

Recognizing that Mexico could not rely on oil revenues, de la Madrid sought to privatize public enterprises. There was an effort to combine structural change and macroeconomic stabilization, with a focus on export-orientated industries (Rodrik, 1992). Power was decentralized to the states to foster competition between their governments and economies and thus help encourage the development of private industries and investment. The overall objective was integration of the Mexican economy into the global economy.

These policies were to have a long-lasting effect on Mexico's economic and social development. The shift to neoliberalism-marked by privatization and deregulation-was radical (Pastor \& Wise, 1997). Relaxation of restrictive FDI laws was a clear signal of the government's desire to attract foreign industries (Lustig, 1992) and allowed Mexican businesses to forge relationships with foreign firms. All of the reforms enabled Mexico to reach its IMF targets for reducing the public sector deficit.

There was a transformation in the relationship between the state and private sector (Schamis, 2002). As private-sector development became crucial to economic revival, its growing importance gave it more influence over the formulation of economic policy and increased access to the government. Mexican economic history can be divided into pre- and post-1982. The crisis saw the development of a new set of economic policies and a new approach to economic management. In the wake of the crisis, Mexico experienced a paradigm shift in macroeconomic policy which constituted a critical juncture (see Hall, 1993). The market, private ownership, and competition were to possess an increasingly important role over the coming years as state control, public ownership, and protectionism were no longer prioritized (Pastor \& Wise, 1997). Beginning in 1982, Mexican economic policy started down a different path, culminating in the North American Free Trade Agreement (NAFTA) in 1994.

This example highlights that the earlier critical junctures framework was capable of providing only a restricted understanding of radical change, in this case macroeconomic policy change (sections 1 and 2). It shows, as pointed out by Matthijs (2012), the importance of the ideational change element (sections 1.1 and 1.2) in the critical juncture framework's capacity for explaining the policy change process. It is the politics of ideas that ultimately determines the outcome of a critical juncture (Capoccia, 2015). Without incorporating an ideational change element in the critical junctures framework, we would be left with a stunted understanding of what happened in Mexico in 1982. 


\section{Conclusion}

The critical junctures literature has, over the years, taken a deeper analytical turn. The earlier punctuated equilibrium understanding of critical junctures, dependent upon the acceptance of institutional stability and the importance of exogenous shocks, contingency, thick description, randomness, and self-reinforcing sequences in the context of historical institutionalism has given way to better understanding derived from a deeper appreciation of the nature of change. Since the turn of the century the critical junctures concept has increasingly sought to explain the patterns present during times of change, and carries a greater appreciate of temporality, choice, reactive sequencing, agency, agents' interests, discourse and the role of ideas in how change occurs.

Seeing how endogenous factors promote change provides for a more complex understanding of critical junctures in public policy as we saw in the case of Mexico in 1982. The newer critical junctures frameworks are sensitive to identifying when policy change does not constitute a critical juncture and can classify the nature of that change. This understanding of the critical junctures concept emphasizes the importance of agency in the context of contingency, and interests, ideas, and discourse in the policy change process. In this context, policy change is defined by the ideas of agents and the communication among them (Peters, 2012).

From this, we can see not only what the consequences are when critical junctures occur, but also what changes come in their wake when they fail to occur (Matthijs, 2012). Moving away from path dependence has advantages considering how unsystematically it has been applied (Howlett, 2009). “The conceptual apparatus of path dependence may not always offer a realistic image of institutional development" particularly given its bias toward stability (Capoccia, 2015, p. 43). Alternatively, the discursive institutionalist approach endogenizes change, explaining how agents bring about change through their preferences and actions (Schmidt, 2010). In this context, discursive institutionalism enables the construction of meaning by agents whose ideational capacities explain how they create policies while communicating about those polices to preserve or to alter them (Blyth, 2002; Matthijs, 2012; Schmidt, 2008, 2010). Thus, path dependence applies only to a limited number of policy events-exogenous shocks leading to critical junctures, whereas endogenous sources of change are much more common and can lead to a range of policy alterations including critical junctures.

John Hogan is a research fellow in the College of Business at the Technological University Dublin. He has published widely in comparative public policy and global lobbying regulations.

\section{References}

Abbott, Andrew. 1997. “On the Concept of Turning Point." Comparative Social Research 16: 85-105.

Acemoglu, Daron, and James A. Robinson. 2012. Why Nations Fail. The Origins of Power, Prosperity and Poverty. London: Crown Business. 
Alarcón, Diana, and Terry McKinley. 1992. “Beyond Import Substitution: The Restructuring Projects of Brazil and Mexico." Latin American Perspectives 19 (2): 72-87.

Ascher, William. 1999. Why Government's Waste Natural Resources: Policy Failures in Developing Countries. Baltimore, MA: The Johns Hopkins University Press.

Bailey, J. J. 1980. “Presidency, Bureaucracy, and Administrative Reforms in Mexico: The Secretariat of Programming and Budget." Inter-American Economic Affairs 34 (2): 27-59.

Baumgartner, Frank R. 2012. "Ideas and Policy Change." Governance 26 (2): 239-58.

Baumgartner, Frank R., and Bryan D. Jones. 1993. Agendas and Instability in American Politics. Chicago: University of Chicago Press.

Beland, Daniel, Martin B. Carstensen, and Leonard Seabrooke, eds. 2016. "Ideas, Power and Public Policy." Journal of European Public Policy 23 (3): 315-17.

Blyth, Mark. 1997. "Moving the Political Middle: Redefining the Boundaries of State Action." The Political Quarterly 68 (3): 217-314.

- 2001. "The Transformation of the Swedish Model: Economic Ideas, Distributional Conflict and Institutional Change." World Politics 54 (1): 1-26.

2002. Great Transformations. New York, NY: Cambridge University Press.

Blyth, Mark, and Matthias Matthijs. 2017. “Black Swans, Lame Ducks, and the Mystery of IPE's Missing Macroeconomy." Review of International Political Economy 24 (2): 203-231.

Boas, Taylor C. 2007. "Conceptualizing Continuity and Change: The Composite-Standard Model of Path Dependence." Journal of Theoretical Politics 19 (1): 33-54.

Calderón-Madrid, Angel. 1997. “Incomplete Adjustment: Fiscal Policy, Private Savings and Current Account Deficits in Mexico Since 1982." In External Finance and Adjustment, Failure and Success in the Developing World, ed. K. Jansen, and R. Vos. London: Macmillan Press Ltd, $121-156$.

Capoccia, Giovanni. 2015. “Critical Junctures and Institutional Change." In Advances in Comparative Historical Analysis, ed. James Mahoney, and Kathleen Thelen. Cambridge: Cambridge University Press, 147-79.

Capoccia, Giovanni, and R. Daniel Kelemen. 2007. “The Study of Critical Junctures: Theory, Narrative, and Counterfactuals in Historical Institutionalism." World Politics 59 (3): 341-69.

Carstensen, Martin B. 2011. "Paradigm Man vs. the Bricoleur: An Alternative Vision of Agency in Ideational Change." European Political Science Review 3 (1): 147-67.

— . 2015. "Conceptualising Ideational Novelty: A Relational Approach." British Journal of Politics and International Relations 17 (2): 284-97.

Carstensen, Martin B., and Matthias Matthijs. 2018. “Of Paradigms and Power: British Economic Policy Making Since Thatcher." Governance 31 (3): 431-447.

Carstensen, Martin B., and Vivien A. Schmidt. 2016. "Power Through, Over and in Ideas: Conceptualizing Ideational Power in Discursive Institutionalism." Journal of European Public Policy 23 (3): 318-37.

Casper, Gretchen, and Michelle M. Taylor. 1996. Negotiating Democracy: Transitions from Authoritarian Rule. Pittsburgh: University of Pittsburgh Press.

Collier, Ruth B., and David Collier. 1991. Shaping the Political Arena: Critical Junctures, the Labour Movement, and Regime Dynamics in Latin America. Princeton, NJ: Princeton University Press.

Cornelius, Wayne A. 1985. “The Political Economy of Mexico under De la Madrid: Austerity, Routinized Crisis, and Nascent Recovery." Mexican Studies 1 (1): 83-124.

Cortell, Andrew P., and Sysan Peterson. 1999. "Altered States: Explaining Domestic Institutional Change." British Journal of Political Science 29 (1): 177-203.

Cox, Robert Henry. 2001. "The Social Construction of an Imperative: Why Welfare Reform Happened in Denmark and the Netherlands but Not in Germany." World Politics 53 (3): 463-98. 
Domínguez, Jorge I., and Rafael F. Castro. 2001. The United States and Mexico: Between Partnership and Conflict. London: Routledge.

Edmonds-Poli, Emily, and David A. Shirk. 2012. Contemporary Mexican Politics, 2nd ed. Plymouth: Rowman \& Littlefield.

Flockhart, Trine. 2005. “Critical Junctures and Social Identity Theory: Explaining the Gap between Danish Mass and Elite Attitudes to Europeanization." Journal of Common Market Studies 43 (2): 251-27.

Gal, John, and David Bargal. 2002. "Critical Junctures, Labour Movements and the Development of Occupational Welfare in Israel." Social Problems 49 (3): 432-54.

Garrett, Geoffrey, and Peter Lange. 1995. "Internationalization, Institutions, and Political Change." International Organization 49 (4): 627-55.

Golob, Stephanie R. 2003. "Beyond the Policy Frontier: Canada, Mexico, and the Ideological Origins of NAFTA." World Politics 55 (3): 361-98.

Haggard, Stephan. 1988. "The Institutional Foundations of Hegemony: Explaining the Reciprocal Trade Agreements Act of 1934." International Organization 42 (1): 91-119.

Hall, Peter A. 1993. “Policy Paradigms, Social Learning, and the State: The Case of Economic Policy Making in Britain." Comparative Politics 25 (3): 275-296.

Hay, Colin. 2006. "Constructivist Institutionalism." In The Oxford Handbook of Political Institutions, ed. R. A. W. Rhode, Sarah A. Binder, and Bert A. Rockman. Oxford: Oxford University Press, 56-74.

Hellinger, Daniel C. 2013. Comparative Politics of Latin America: Democracy At Last? 2nd ed. New York, NY: Routledge.

Hogan, John. 2006. "Remoulding the Critical Junctures Approach." Canadian Journal of Political Science 39 (3): 657-79.

Hogan, John, and David Doyle. 2007. “The Importance of Ideas: An A Priori Critical Juncture Framework." Canadian Journal of Political Science 40 (4): 883-910.

Hogan, John, and Sharon Feeney. 2012. "Crises and Policy Change-The Role of the Political Entrepreneur." Risk, Hazards \& Crisis in Public Policy 4 (2): 1-16.

Hogan, John, and Nicola Timoney. 2017. “A Discursive Institutionalist Approach to Understanding the Changes in Irish Social Partnership Policy After 2008." Journal of the Statistical and Social Inquiry Society of Ireland 45 (1): 67-92.

Howlett, Michael. 2009. "Process Sequencing Policy Dynamics: Beyond Homeostasis and Path Dependency." Journal of Public Policy 29 (3): 241-62.

Kahler, M. 1990. “Orthodoxy and its Alternatives: Explaining Approaches to Stabilization and Adjustment." In Economic Crisis and Policy Choice: The Politics of Adjustment in the Third World, ed. J. M. Neslson. Princeton: Princeton University, 33-61.

Karl, Terry Lynn. 1997. The Politics of Plenty: Oil Booms and Petro-States. Berkeley: University of California Press.

Kingdon, John W. 1995. Agendas, Alternatives, and Public Policy, 2nd ed. New York, NY: Harper.

Krasner, Stephen D. 1984. "Approaches to the State: Alternative Conceptions and Historical Dynamics." Comparative Politics 16 (2): 223-246.

Ladi, Stella. 2011. "Think Tanks, Discursive Institutionalism and Policy Change." In Social Science and Policy Challenges: Democracy, Values and Capacities, ed. Georges Papanagnou. Paris: UNESCO, 20520.

Legro, Jeffrey W. 2000. “The Transformation of Policy Ideas.” American Journal of Political Science 44 (3): 419-32.

Lindblom, Charles E. 1959. “The Science of Muddling Through.” Public Administration Review 19 (2): 79-88. 
Lipset, S. M., and S. Rokkan. 1967. "Cleavage Structures, Party Systems, and Voter Alignments." In Party Systems and Voter Alignments: Cross-National Perspectives, ed. S. M. Lipset, and S. Rokkan. New York: Free Press, 1-64.

Looney, Robert E. 1985. Economic Policymaking in Mexico: Factors Underlying the 1982 Crisis. Durham, NC: Duke University.

Luna, Matilda., Ricardo Tirado, and Francisco Valdes. 1987. “Businessmen and Politics in Mexico, 1982-1986." In Government and Private Sector in Contemporary Mexico, ed. S. Maxfield, and R. Anzaldua. San Diego: Center for U.S.-Mexican Studies, 13-44.

Lustig, Nora. 1992. Mexico: The Remaking of the Economy. Washington, D.C.: The Brookings Institute.

Mahoney, James. 2000. "Path Dependence in Historical Sociology." Theory and Society 29 (4): 507-48.

— 2001. "Path Dependent Explanations of Regime Change: Central America in Comparative Perspective." Studies in Comparative International Development 36 (1): 111-41.

— . 2003. "Long-Run Development and the Legacy of Colonialism in Spanish America." American Journal of Sociology 109 (1): 50-106.

Malkin, L., J. Greenwald, and M. Earle. 1983. The Cartel is Losing its Clout. Time Magazine (January 1): 27.

March, James G., and Johan P. Olsen. 1984. “The New Institutionalism: Organisational Factors in Political Life." The American Political Science Review 78 (3): 734-749.

_ 2005. "Elaborating the "New Institutionalism." In The Oxford Handbook of Political Institutions, ed. R. A. W. Rhodes, Sarah A. Binder, and Bert A. Rockman. Oxford: Oxford University Press, 3 22.

Matthijs, Matthias. 2012. Ideas and Economic Crises in Britain from Attlee to Blair (1945-2005). Abingdon: Routledge.

McCaughan, Edward J. 1993. “Mexico's Long Crisis: Toward New Regimes of Accumulation and Domination." Latin American Perspective 20 (3): 6-31.

Nelson, Joan M. 1990. Economic Crisis and Policy Change. Princeton: Princeton University.

Pastor, Robert A., and Jorge G. Castañeda. 1988. Limits to Friendship: The United States and Mexico. New York, NY: Vintage Books.

Pastor, Manuel, and Carol Wise. 1997. "State Policy, Distribution and Neoliberal Reform in Mexico." Journal of Latin American Studies 29 (2): 419-56.

Peters, B. Guy. 2012. Institutions in Political Science: The New Institutionalism, 3rd ed. New York, NY: Continuum.

Philip, G. 2014. “Crises and Their Consequences in Latin America: Mexico in 1982 and 1994 and Venezuela in 1994." In Moments of Truth: The Politics of Financial Crises in Comparative Perspective, ed. F. Panizza, and G. Philip. New York, NY: Routledge, 11-26.

Pierson, Paul. 1993. “When Effect Becomes Cause: Policy Feedback and Political Change." World Politics 45: 595-628.

— 2000. "Increasing Returns, Path Dependency, and the Study of Politics." American Political Science Review 94 (2): 251-67.

- 2004. Politics in Time: History, Institutions, and Social Analysis. Princeton, NJ: Princeton University Press.

Rayner, Jeremy. 2015. "Is There a Fourth Institutionalism? Ideas, Institutions and the Explanation of Policy Change." In Policy Paradigms in Theory and Practice, ed. John Hogan, and Michael Howlett. Basingstoke: Palgrave, 61-80.

Rodrik, Dani. 1992. “The Limits of Trade Policy Reform in Developing Countries." Journal of Economic Perspectives 6 (1): 87-105.

Sanderson, Steven E. 1983. "Presidential Succession and Political Reality in Mexico." World Politics 35 (3): 315-34. 
Schamis, Hector E. 2002. Re-forming the State: The Politics of Pirvitazition in Latin America and Europe. Michigan: University of Michigan Press.

Schedler, Andreas. 2007. "Mapping Contingency." In Political Contingency: Studying the Unexpected, the Accidental and the Unforeseen, ed. Ian Shapiro, and Sonu Bedi. New York: New York University Press, 54-78.

Schmidt, Vivien A. 2002. The Futures of European Capitalism. Oxford: Oxford University Press.

— . 2008. "Discursive Institutionalism: The Explanatory Power of Ideas and Discourse." Annual Review of Political Science 11 (3): 303-26.

— 2010. “Taking Ideas and Discourse Seriously: Explaining Change Through Discursive Institutionalism as the Fourth 'New Institutionalism." European Political Science Review 2 (1): 1-25.

Schmidt, Vivien A., and Mark Thatcher, ed. 2013. Resilient Liberalism in Europe's Political Economy. Cambridge: Cambridge University Press.

Sheingate, Adam D. 2003. "Political Entrepreneurship, Institutional Change, and American Political Development." Studies in American Political Development 17 (2): 185-203.

Slater, Dan, and Erica Simmons. 2010. "Informative Regress: Critical Antecedents in Comparative Politics." Comparative Political Studies 43 (7): 886-917.

Smith, P. 1990. "Mexico Since 1946." In The Cambridge History of Latin American: 1930 to the Present, vol VII, ed. L. Bethell. Cambridge: Cambridge University Press, 83-160.

Soifer, Hillel. 2012. “The Causal Logic of Critical Junctures." Comparative Political Studies 45 (2): 15721597.

Solís, Leopoldo. 1981. Economic Policy Reform in Mexico. A Case Study for Developing Countries. Elmsford, NY: Pergamon.

Streeck, Wolfgang, and Kathleen Thelen. 2005. "Introduction: Institutional Change in Advanced Political Economies." In Beyond Continuity. Institutional Change in Advanced Political Economies, ed. Wolfgang Steeck, and Kathleen Thelen. Oxford: Oxford University Press, 1-39.

Thelen, Kathleen. 2004. How Institutions Evolve: The Political Economy of Skills in Germany, Britain, the United States and Japan. Cambridge: Cambridge University Press.

Thelen, Kathleen, and Sven Steinmo. 1992. "Historical Institutionalism in Comparative Politics." In Structuring Politics: Historical Institutionalism in Comparative Analysis, ed. Sven Steinmo, Kathleen Thelen, and Frank Longstreth. Cambridge: Cambridge University Press, 1-32.

Tilly, C. 1975. The Formation of Nation States in Western Europe. Princeton, NJ: Princeton University Press.

Vargas, Vicente. 2004. "The Political Dynamic of the Conflict in Chiapas: A History of its Critical Junctures." Paper presented at Centre of Latin American Studies research day, University of Cambridge, 24 May 2004.

Walker, Louise E. 2013. Waking from the Dream: Mexico's Middle Class After 1968. Stanford, CA: Stanford University Press.

Weir, Margaret. 1992. "Ideas and the Politics of Bounded Innovation." In Structuring Politics: Historical Institutionalism in Comparative Analysis, ed. Sven Steinmo, Kathleen Thelen, and Frank Longstreth. Cambridge: Cambridge University Press, 188-216.

Wilder, Matt, and Michael Howlett. 2014. "The Politics of Policy Anomalies: Bricolage and the Hermeneutics of Paradigms." Critical Policy Studies 8 (2): 183-202.

Wolff, Sarah. 2012. The Mediterranean Dimension of the European Union's Internal Security. Basingstoke: Palgrave.

Yoshimatsu, Hidetaka. 2014. Comparing Institution-Building in East Asia: Power Politics, Governance, and Critical Junctures. Basingstoke: Palgrave Macmillan. 